\title{
Tourisme et migration, entre logiques des marchés et système des mobilités : revue bibliographique
}

\section{Olivier Dehoorne}

\section{(2) OpenEdition \\ 1 Journals}

Édition électronique

URL : https://journals.openedition.org/remi/2631

DOI : 10.4000/remi.2631

ISSN : $1777-5418$

Éditeur

Université de Poitiers

\section{Édition imprimée}

Date de publication : 1 mars 2002

Pagination : 113-121

ISBN : 2-911627-30-X

ISSN : 0765-0752

\section{Référence électronique}

Olivier Dehoorne, «Tourisme et migration, entre logiques des marchés et système des mobilités : revue bibliographique ", Revue européenne des migrations internationales [En ligne], vol. $18-\mathrm{n}^{\circ} 1$ | 2002, mis en ligne le 09 juin 2006, consulté le 16 avril 2022. URL : http://journals.openedition.org/remi/2631 ; DOI : https://doi.org/10.4000/remi.2631

Ce document a été généré automatiquement le 16 avril 2022.

(c) Université de Poitiers 


\title{
Tourisme et migration, entre logiques des marchés et système des mobilités : revue bibliographique
}

\author{
Olivier Dehoorne
}

1 Les études consacrées aux interrelations tourisme-travail-migration sont assez récentes. Les premiers travaux abordant les liens entre tourisme et migration ne remontent qu'aux années soixante-dix; la thématique est alors abordée dans le cadre de monographies sur le tourisme. Les espaces privilégiés sont les littoraux méditerranéens de l'Europe, les Alpes, et quelques espaces insulaires (les îles Baléares, Hawaii, Bali) qui constituent d'intéressants cas d'école qui permettent d'analyser la structuration de ces nouvelles économies sur plusieurs décennies. Les auteurs attirent l'attention sur l'appel de main-d'œuvre provoqué par ce marché naissant. Des études sur le fait migratoire complètent ensuite les approches, mettant notamment l'accent sur les retours au pays et les investissements réalisés dans le secteur touristique.

2 La convergence de ces flux de nature opposée en un même lieu et les inter-actions qui se dessinaient n'ont pas fait l'objet d'étude spécifique. Néanmoins les travaux réalisés sur les régions touristiques les plus anciennement développées contiennent d'intéressantes informations sur les processus de construction d'un lieu touristique et de l'émergence des logiques migratoires, qui peuvent être mises en parallèle avec les situations observables aujourd'hui dans des stations émergentes.

Dés les années quatre-vingts, les recherches mettent l'accent sur la complexification des flux notamment avec l'installation plus ou moins permanente de nouveaux résidents dans ces espaces longtemps caractérisés par l'importance de l'émigration. Ce sont principalement des retraités venus de foyers urbains et industriels de l'Europe du Nord, qui s'installent durablement dans ces zones touristiques. On découvre alors la vertu « peuplante » du tourisme qui s'affirme comme l'un des moteurs de la croissance des nouvelles régions urbaines, spécialisées dans les services, attirant ainsi une seconde génération de flux migratoires. Les chercheurs anglais et espagnols se rejoignent sur les côtes méditerranéennes pour enquêter sur des flux multiformes combinant les 
arrivées des ressortissants britanniques et celles des pays du Maghreb, et le développement de nouvelles filières migratoires s'inscrivant dans une logique mondiale. Des études similaires sont conduites sur les côtes caraïbes et australiennes notant l'extension du phénomène en Asie avec les installations de Japonais et aussi de Sud-coréens dans les Mers du Sud.

4 Après une phase de relative dispersion, où de nombreux travaux ont souligné les logiques spécifiques qui s'établissent entre tourisme et migration, un projet de recherche international "Tourisme et migration: nouveaux rapports entre production et consommation" vient d'être élaboré en 1999 dans le cadre de Groupe d'étude "Géographie du tourisme, des loisirs et du changement global » de l'Union Géographique Internationale, présidé par Michael C. Hall ${ }^{1}$. Les travaux prévus dans le cadre de ce projet de recherches international seront coordonnés par les professeurs Allan M. Williams (Université d'Exeter, R.U.) et Michael C. Hall (Université d'Otago, NouvelleZélande). Le contenu du projet est consultable sur le site Internet suivant: http:// www.for.nau.edu/geography/igust/migration.html.

5 À la suite d'un premier cycle de rencontres ${ }^{2}$, la revue Tourism Geographies a consacré un numéro thématique "Tourism and Migration $»^{3}$ permettant de présenter un premier état des travaux. Un ouvrage coordonné par Michael C. Hall et Allan M. Williams, Tourism and Migration: new relationsships between Production and Consuption doit paraître prochainement ${ }^{4}$.

6 Cette thématique est devenue l'objet principal d'un nouveau groupe d'étude de l'UGI, créé en 2000, "Global change and human mobility" dit "GLOBILITY ». Les premières rencontres "Human mobility in a Borderless world?", organisé à l'Université Gabriele d'Annunzio, à Pescara (Italie) ont permis de réunir des spécialistes des migrations et du tourisme ${ }^{5}$.

7 Les références bibliographiques rassemblées ici ont été organisées en six parties. La première concerne des études plus générales, essentiellement en langue française, permettant de poser les concepts et d'introduire des avancées sur la notion de mobilité avec des approches privilégiant les migrations ou le tourisme selon les spécialistes. La seconde partie repose principalement sur des travaux de langue anglais qui mettent en évidence le fonctionnement du marché touristique, tant à l'échelle globale qu'au niveau local. L'objectif est de caractériser le marché, de comprendre son fonctionnement, ses règles et donc les relations privilégiées, parfois obscures, qui se tissent avec les migrations. Outre le fait qu'un lieu touristique peut paraitre un eldorado aux yeux du travailleur émigré, il convient de rappeler que ce marché ne peut pas fonctionner sans migration de main-d'œuvre, sans rotation des travailleurs. La troisième partie met l'accent les petits entrepreneurs et autres migrants sans qualification précise qui développent des stratégies individuelles dans les lieux touristiques. Les parties suivantes concernent les liens entre les investissements touristiques et le retour des émigrés (partie quatre), les transferts d'activités, déplacements de retraite et multirésidence caractérisant des flux nord-sud (partie cinq), puis introduit les bases de réflexions sur les liens entre flux touristiques et diasporas (partie six).

1. Migration, tourisme, éléments de réflexion sur le système des mobilités

8 CAZES Georges (1998) Les mobilités touristiques internationales, in Rémy Knafou ed., La Planète «nomade ». Les mobilités géographiques aujourd'hui, Belin, pp. 77-91 
DESJEUX Dominique et BONNET Michel (2000) Les significations multiples de la mobilité, in Michel Bonnet et Dominique Desjeux eds. Les territoires de la mobilité, Paris, PUF, pp. 15-19.

DI MEO Guy ed. (1996) Les territoires du quotidien, Paris, L'Harmattan, 207 p.

GOLINI A, BONIFAZI C, RIGHI A (1993), A general framework for the European migration system in the 1990's, in Russell King ed., The new geography of European migration, London : Belhaven, pp. 67-82.

KNAFOU Rémy et alii (1997) Une approche géographique du tourisme, L'Espace Géographique, n³, pp. 193-204.

LEVY Jacques (1998) Nous habitons des lieux multiples, in Rémy Knafou éd. La Planète « nomade ». Les mobilités géographiques aujourd'hui, Belin, pp. 193-197.

LEVY Jacques (2000) Les nouveaux espaces de la mobilité, in Michel Bonnet et Dominique Desjeux éds. Les territoires de la mobilité, Paris, PUF, pp. 155-170.

SIMON Gildas (1998) La planétarisation des migrations internationales, in Rémy Knafou ed., La Planète « nomade ». Les mobilités géographiques aujourd'hui, Belin, pp. 59-76.

6 TARRIUS Alain (1989) Anthropologie du mouvement, Caen, Paradigme, 192 p.

THUMERELLE Pierre-Jean (2001) Hommes et espace : indépendance et interdépendance, in Pierre-Jean Thumerelle ed., Explications en géographie. Démarches, stratégies et modèles, Paris, SEDES, pp. 113-126.

2. Tourisme et travail : logiques des marchés et migrations

18 AITKEN Carmen, HALL C. Michael (2000) Migrant and foreign skills and their relevance to the tourism industry, Tourism geographies, 2,1, pp. 6-86.

ANDRONIKOU A (1993) The hotel industry in Cyprus : problems and future prospects, Tourism management, 14(1), pp. 67-70.

BAGGULEY P (1987) Flexibility, restructuring and gender. Changing employment in Britain's hotels, Lanchaster: University of Lanchaster, Lanchaster regionalism group working paper, $\mathrm{n}^{\circ} 24$.

BAGGULEY P (1990) Gender and labour flexibility in hotel and catering, Service industries journal, 10(4), pp. 737-747.

BALL R M (1988) Seasonality : a problem for workers in the tourism labour market? Service industries journal, 8(4), pp. 501-513.

BALL R M (1989) Aspects of tourism , seasonality and local labour markets, Area, 21(1), pp. 35-45.

BERRIANE Mohamed (1983) Tourisme et emploi : le cas d'Agadir, Revue de Géographie du Maroc, 7, pp. 21-33.

BRITTON S (1991) Tourism, capital and place : towards a critical geography, Environment and planing D : Society and Space, 9, pp. 451-478.

BROTHERTON B and SAW J (1996) Towards an identification and classification of critical success factors in UK hotels, International journal of hospitality management 15(2), pp. 112-135.

BULL P and CHURCH A (1994) The geography of enployment change in the hotel and catering industry of Great Britain in the 1980's : a subregional perspective, Regional studies, 28, pp. 13-25. 
CHARMES J, DABOUSSI R, LEBON A (1993) Population, employement and migration in the countries of the mediterranean basin, Geneva, International Labour office, Mediterranean Information Exchange System on International migration and Employment, Paper 93/1E.

DOHERTY L and STEAD L (1998) The gap between male and female pay: what does the case of hotel and catering tell us? The services industry journal, 18(4) pp. 126-144.

DWYER L, BURNLEY L, FORSYTH P and MURPHY P (1993) Tourism-immigration interrelationship, Camberra, Australian government publishing service.

FAVER J A M (1984) Tourism and employment in the Gambia, Annals of tourism research, 11, 2, pp. 249-265.

GANNON J, JOHNSON K (1995) The global hotel industry: the emergence of continental hotel companies, Progress in tourism and hospitality research, 1(1), pp. 31-42.

HENNESSY S (1994) Female employment in tourism employment in southwest England, in V. Kinnaird and D. Hall eds., Tourism : a gender analysis, London, Wiley, pp. 35-51.

IOANNIDES D and DEBBAGE K (1998b) Neo-fordism and flexible specialization in travel industry: dissecting the polyglot, in D.Ioannides and K. Debbage eds., The economic geography of the tourism industry : a supply side analysis, London, Routledge pp. 99-122.

JORDAN F (1997) An occupational hazard? Sex segregation in tourism employment, Tourism management, 18(8), pp. 525-534.

KING Russell (1995) Tourism, labour and International Migration, in Allan M. Williams and Armando Montanari eds., European Tourism Regions, Spaces and Restructuring. Restructuring in Europe, John Wiley and Sons Ltd, pp. 177-190.

KINNAIRD Vivian, HALL Derek (1996) Understanding tourism processes : a genderaware framework, Tourism Management, 17, 2, pp. 95-102.

KONTOGEOGOPOULOS N (1998) Accomodation employment patterns and opportunities, Annals of trourism research, 25, pp. 314-339.

LAWSON F R (1982) Trends in business tourism management, Tourism management, 3, pp. 298-302.

LEHMANN A C (1980) Tourists, black markets and regional development in West Africa, Annals of tourism research, 7(1), pp. 102-119.

1 LONT V H, KINDON S L (1997) Gender and tourism development in Balinese villages, in T.M. Sinclair ed., Gender, work in tourism, London, Routledge, pp. 91-119.

2 MINERBI Luciano (1994) Sustainability versus growth in Hawai'i, in I. Aoude ed. Social Process in Hawai'i, Honolulu, University of Hawai'i, vol. 35, pp. 145-160.

MOMSEN J H ( 1994) Tourism, gender and the development of the Caribbean, in V. Kinnaird and D. Hall eds. Tourism: A gender analysis, John Wiley and Sons Ltd, pp. 106-120.

44 MONTANARI Armando, CORTESE A (1993b) South to North migration in the Mediterranean perspective, in Russell King ed., Mass migration in Europe: The legacy and the future, London : Belhaven press.

SALVÀ TOMÀS Pere (1991) La population des îles Baléares pendant 40 ans de tourisme de masse (1950-1990), Méditerranée, 1, pp. 7-14. 

Dordrecht-London, Kluwer Academic Publishers, $13 \mathrm{p}$. of the 1980's, Environment and planning, 24, pp. 821-832. Inforgeo (As : Portuguesa de Geografos, Lisbon), pp. 7-20. Chichester, JohnWiley and Sons, pp. 163-176. Town planning review, 59, pp. 81-104. review, 1(3), pp. 243-256. Corporation, pp. 128-145. Development J, 27, 4, pp. 361-370. Thailand, Annals of tourism research, 9(2), pp. 189-205. Annals of tourism research, 12(1), pp. 5-29. York : Cognizant Communication Corporation, pp. 30-41.

SALVÀ TOMÀS Pere (2002) Foreign immigration flows as consequence of tourist development of the Balearic Islands (Spain), in C Michael Hall and Allan M. Williams eds., Tourism and Migration: News relationships between production and consumption,

SINCLAIR M Thea (1997) Issues and theories of gender and work in tourism, in M. Thea Sinclair ed., Gender, work in tourism, London/New York: Routledge, pp. 1-15.

SWAIN M B (1995) Gender in tourism, Annals of tourism research, 22(2) pp. 247-266.

TOWNSED A (1992) New direction in the growth of tourism employment? Propositions

WILLIAMS Allan M (1993) Tourist and economic transformation in Greece and Portugal,

WILLIAMS Allan M. (1995) Capital and transnationalisation of tourism, in Armando Montanari and Allan M. Williams eds., European tourism : regions, spaces and restructuring,

WILLIAMS Allan M. and HALL C. Micheal (2000) Tourism and migration: new relationships between production and consuption, Tourism Geographies, 2, 1, pp. 5-27.

WILLIAMS Allan M, MONTANARI Armando (1995) Introduction : tourism and economic restructuring in Europe, in Allan M Williams and Armando Montanari eds., European tourism : regions, spaces and restructuring, Chichester, John Wiley andd Sons, pp. 1-15.

WILLIAMS Allan M and SHAW G (1988) Tourism : candy floss industry or job generator?

3. Marchés touristiques locaux, petits entrepreneurs et stratégies individuelles

BRAS Karin and DAHLES Heidi (1998) Women enterpreneurs and beach tourism in Sanur, Bali. Gender, employment opportunities and government policy. Pacific tourism

BRAS Karin and DAHLES Heidi (1999) Pathfinder, Gigolo, and Friend: Diverging Entrepreneurial Stratégies of Tourist Guides on Two Indonesian Islands, in H. Dahles and K. Bras eds., Tourism and Small Entrepreneurs. Development, National Policy, and Entrepreneurial Culture: Indonesian Cases, New York, Cognizant Communication

BROWN N. (1992) Beachboys as culture brokers in Bakau Town, the Gambia, Community

COHEN Eric (1982) Marginal paradises : Bungalow tourism on the islands of Southern

COHEN Eric ( 1985) The tourist guide: The origins, structure and dynamics of a role.

CRICK M (1992) Life in the informal sector : street guides in Kandy, Sri Lanka, in D. Harrison ed., Tourism in the less developed countries, Londoln : Belhave Press, pp. 135-147.

61 DABLES Heidi (1998) Of birds and fishes. Streetguides, tourists and sexual encounteres in Yogyakarta, Indonesia, in Martin Oppermann ed, Sex tourism and prostitution, New

DABLES Heidi (1999) Tourism and Small Entrepreneurs in Developing Countries: A Theorical Perspective in H. Dahles and K. Bras eds., Tourism and Small Entrepreneurs. 
Development, National Policy, and Entrepreneurial Culture: Indonesian Cases, New York, Cognizant Communication Corporation, pp. 1-19.

EVERS H D and MEHMET O (1994) The management of risk: Informal trade in Indonesia, World development, 22(1), pp. 1-9.

KIETTHUBTHEW T et SATHAPORN C (1987) The migration of Northern women, prostitution and tourism in Songkhala - Hat Yai, in S. Prasith-Rathsind eds., Population and development projects in Thailand, Bangkok, Microlevel Studies program, pp. 140-183.

SHAW G and WILLIAMS Allan M (1998) Entrepreneurship, small business culture and tourism development, in D. Ioannides and K. Debbage eds., The economic geography of the tourist industry : a supply side analysis, London, Routledge, pp. 235-255.

TIMOTHY D J and WALL G (1997) Selling to tourists. Indonesian street vendors, Annals of Tourism research, 24(4), pp . 322-340.

VAN der DUIM R ( 1997) The role of small enterpreneurs in the development of sustainable tourism in Costa Rica, in Heidi Dahles ed., Tourism, small entrepreneurs, and sustainable development. Cases from developing countries, Tilburg : ATLAS, pp. 35-48.

VAN GEMERT Hanneke, VAN GENUGTEN Esther and DAHLES Heidi (1999) Tukang Becak: the Pedicap Men of Yogyakarta, in H. Dahles and K. Bras eds., Tourism and Small Entrepreneurs. Development, National Policy, and Entrepreneurial Culture: Indonesian Cases, New York, Cognizant Communication Corporation, pp. 97-111.

4. Tourisme et retours des émigrés

BENNETT B.C.(1979) Migration and rural community viability in central Dalmatia (Croatia), Yugoslavia, Papers in Anthropology, 20(1), pp. 75-83.

CAVACO Carminda (1980) Tourismo e demografia no Algave, Lisbon, Editorial Progresso Social e Democracia.

CAVACO Carminda (1993) A place in the sun : return migration and rural change in Portugal, in Russell King ed. Mass Migrations in Europe : the Legacy and the Future, London, Belhaven pp. 174-191.

CERASE F P (1974) Migration and social change : expectation and reality. A study of return migration from United States to Italy, International migration review, 8, pp. 245-262.

73 KENNA M E (1993) Return migration and tourism development: one example from the Cyclades, Journal of modern greek studies, 11(1), pp. 75-95.

KING Russell ( 1984) Population mobility: emigration, return migration and internal migration, in Allan M. Williams ed., Southern Europe transformed: political and economic change in Greece, Italy, Portugal and Spain, London, Harper and Row, pp. 145-178.

KING Russell (1986) Return migration and regional economic development: an overview, in Russell King ed., Return migration and regional economic problems, London, Croom Helm, pp. 1-37.

KING Russell, MORTIMER J, STRACHAN A J (1984) Return migration and tertiary development : a Calabrian case-study, Antropological Quarterly, 57(3), pp. 112-124.

77 LEWIS J R, WILLIAMS Allan M (1986) The economic impact of return migration in Central Portugal, in Russsell KING ed., Return migration and regional economic problems, Chichester : Wiley, pp. 100-128. 
MENDONZA E (1982) Benefits of migration as a personal strategy in Nazare, Portugal, International migration review, 16(3), pp. 635-645.

5. Tourisme, transfert d'activité, multi-résidence

BARKE M (1991) The growth and changing pattern of second homes in Spain in the 1970's, Scottish geographical magazine, 107, pp. 12-21.

BULLER H., HOGGART K. (1994) Vers une campagne européenne : les Britanniques en France rurale, L'Espace Géographique, n 3, pp. 263-273.

CRIBIER Françoise and KYCH Alexandre (1993) A comparison of retirement migration from Paris and London. Environment and planning, 25, pp. 1399-1420.

DUHAMEL Philippe (1997) Les résidents étrangers européens à Majorque (Baléares). Pour une analyse de la transformation des lieux touristiques, Thèse, Paris VII, 750 p.

EATON M (1995) British expatriate service provision in Spain's Costa del Sol, Services industries journal, 15, pp. 251-266.

FLOGNFELDT Thor (2002) Second-home ownership : a sustainable semi-migration, in Michael C. Hall and Allan M. Williams eds., Tourism and migrations: New relationships between production and consumption, Kluwer, Dordrecht, pp. 187-204.

HAAS W H and SEROW W J (1997) Retirement migration decision making : life course mobility, sequencing of events, social ties and alternatives, Journal of community development society, 28(1), pp. 116-130.

HAMILTON O (1982) The divine country : the British in Tuscany 1372-1980, Londres, A. Deutsch.

JURDAO F y SANCHEZ M (1990) España, asilo de Europa, Barcelona: Editorial Planeta.

KIM K. (1994) The political economy of foreign investment in Hawai'i, in A. Ibrahim ed. Social Process in Hawai'i, Honolulu, University of Hawai'i, pp. 40-55.

9 KING Russell and RYBAZCUK K (1993) Southern Europe and the international division of labour: from emigration to imigration, in Russell King ed., The new geography of european migration, London : Belhaven.

KING Russell, WARMES Anthony $M$ and WILLIAMS Allan M (1998) International retirement migration in Europe, International journal of population geography, 4(2), pp. 91-111.

1 KING Russell, WARMES Anthony M and WILLIAMS Allan M (2000) Sunset lives : British retirement to Southern Europe, Oxford : Berg.

MADDEN L (1999) Making money in the sun : the development of British and Irish owned business in the Costa del Sol, Brighton, University of Sussex, Research papers in geography, 36 .

MCHUGH K, HOGAN T D, HAPPEL S K (1995) Multiple residence and cyclical migrations : a life cours perspective, Professional geographer, 47, pp. 251-267.

94 MCHUGH K and MING R C (1992) Canadian snowbirds in Arizona, Journal of applied recreation research, 17, pp. 255-277.

MING R C (1977) Tracking snowbirds in Australia: winter sun seekers in Far North Queensland, Australian geographical studies, 35(2), pp. 168-182. 
MÜLLER Dieter K. (1999) German Second Homes Owners in the Swedish Countryside : On the Internationalization of the Leisure Space, Dept. of Social and Economic geography, Umea, Sweden, Sweden, 1999.

MÜLLER Dieter K. (2002) German second home developement in Sweden, in C. Michael Hall and Allan M. Williams eds., Tourism and Migration: new relationships between Production and Consuption, Kluwer, Dordrecht, pp. 169-185.

MULLINS P (1990) Tourist cities as new cities: Australia's Gold Coast and Sunshine Coast, Australian Planner, 28(3), pp. 37-41.

MURPHY P A (1981) Patterns of coastal retirement migration, in A. Howe ed., Towards an older Australia, St. Lucia : University of Queensland Press, pp. 301-314.

O'REILLY K (1995a) A new trend in European migration: contemporary British migration to Fuengirola, Costa del Sol, Geographical viewpoint, 23, pp. 25-36.

O'REILLY K (1995b) Constructing and managing identities : 'residential tourists', or a British expatriate community in Fuengirola, southern Spain, Essex graduate journal of Sociologie, 1, pp. 25-37.

O'REILLY K (2000) Trading intimacy for liberty: British women on the Costa del Sol, in F. Anthias and G. Lazaridis eds., Gender and migration in Southern Europe : women on the move, London, Berg, $263 \mathrm{p}$.

PHILLIPS M (1993) Rural gentrification and processes of class colonization, Journal of rural studies, 9(2), pp. 123-140.

RODRIGUEZ Vicente (2001) Tourism as a recruting post for retirement migration, Tourism geographies, 3, pp. 52-63.

RODRIGUEZ Vicente, FERNANDEZ-MAYORALAS and ROYO F (1998) European retirees on the Costa del Sol: a cross-national comparison, International journal of population geography, 4(2), pp. 183-200.

ROYA P (1994) El turismo residencial en Andalucía, Boletín economico de Andalucía, 17, pp. 21-31.

SIMON R and MINNERY J (1998) Why people move to the 'Sun-Belt': a case study of long - distance migration to the Gold Coast, Australia, Urban studies, 35(2), pp. 193-214.

WARNES M.A. (1991) Migration to and seasonal residence in Spain of Northern European elderly people, European Journal of Gerontology, vol. 1, part. 1, p. 59.

WARNES M.A. (1993) The development of Retirement Migration in Great-Britain, Espace, Populations, Sociétés, nº 3, pp. 451-464.

WARNES A M (1994) Permanent and Seasonal International retirement migration : the prospects for Europe, Netherlands geographical studies, 173, pp. 69-81.

WARNES T and PATTERSON G (1998) British retirees in Malta : components of the crossnational relationship, International journal of Population geography, 4(2), pp. 113-133.

2 WILLIAMS Allan M, KING R and WARNES T (1997) A place in the sun: International retirement migration from Northern to Southern Europe, European urban and regional studies, 4(2), pp. 15-34.

WILLIAMS Allan M., KING Russell, WARNES Anthony, PATTERSON Guy (2000) Tourism and international retirement migration: new forms of an old relationship in southern Europe, Tourism Geographies, 2,1, pp. 28-49. 
114 WILLIAMS Allan M, PATTERSON (1998) An empire lost but a province gained : a cohort analysis of British international retirement in the Algarve, International journal of population geography, 4(2), pp. 113-134.

6. Tourisme et diaspora

115 FENG K and PAGE S J (2000) An exploratory study of the tourism, migration-imigration nexus : travel experiences of Chinese residents in New Zealand, Current Issues in tourism, vol 3, pp. 246-281.

116 HITCHCOX L (1994) Relocation in Vietnam and outmigration, in J. Brown and W. Foot eds., Migration : the asian experience, Basingstoke : Macmillan, pp. 202-220.

KANG Sophie (1999) Tourism, migration and ethnicity : an exploratory study of Korean New-Zeelanders travel patterns. Masters in business studies research report, Massey University Albany, Auckland.

KANG Sophie Kyung-Mi, PAGE Stephen J. (2000) Tourism, migration and emigration : travel patterns of Korean-New Zealanders in the 1990s, Tourism Geographies, 2,1, pp. 50-65.

KING B E, GAMAGE M A (1995) Measuring the value of the ethnic connection: expatriate travelers from Australia to Sri Lanka, Journal of travel research, 33(2), pp. 46-50.

KUZNETS P (1987) Koreans in Australia : recent migration from South Korea to the United States, in Klein S The economics of Mass migration in the twentieth century, New York, Paragon, pp. 47-70.

WOO K and PAGE Stephen J (1999) Case study : Tourist demand in East Asia Pacific - the case of the South Korean outbord market and activity patterns in New Zeland, in C. Michael Hall and Stephen J Page eds., The geography of tourism and recreation: environment, place and space, London, Routledge, pp. 70-75.

YOON H and KIM S (1997) An analysis of occupation of Korean imigration in Auckland, New Zealand, Journal of Korean geography, 32(4), pp. 491-450.

\section{NOTES}

1. -http://divcom.otago.ac.nz

2. -Hawaï (23-27 mars 1999), Flagstaff, Arizona (20-23 octobre 1999) et Séoul (26 août-1 septembre 2000). Le site du groupe d'étude présente ces rencontres et des liens permettent d'obtenir le détail des communications.

3. -February 2000, vol. 2, $\mathrm{n}^{\circ} 1$.

4. -Ed. Kluwer, Dordrecht, sous presse.

5. -Rencontres de Pescara, 20-22 avril 2001, organisées par Armando Montanari. Toutes les informations relatives aux axes de recherche et aux prochains colloques figurent sur le site suivant www.bun.kyoto-u.ac.jp/geo/globility/. Des liens permettent d'accéder au programme du colloque ainsi qu'aux différents résumés en attendant la prochaine parution des actes (pour 2002). 


\section{AUTEUR}

\section{OLIVIER DEHOORNE}

Maître de conférences, Migrinter (Université de Poitiers-CNRS), 99 avenue du Recteur Pineau, 86000 Poitiers, France, et MIT, Université de Paris VII. dehoorneo@hotmail.com 